\title{
Characterization of $\alpha 3$ Glycine Receptors with Ginkgolide B and Picrotoxin
}

\author{
Sampurna Chakrabarti, Anil Neelakantan, Malcolm M. Slaughter \\ Department of Physiology and Biophysics, Jacobs School of Medicine, State University of \\ New York at Buffalo. Buffalo, NY, USA
}

Corresponding author: Malcolm M. Slaughter, email: mslaught@buffalo.edu 


\begin{abstract}
Ginkgolide B (GB) and picrotoxin (PTX) are antagonists of the major inhibitory receptors of the central nervous system: GABA and glycine receptors (GlyRs). GlyRs contain one or more of the four alpha subunit isoforms of which $\alpha 1$ and $\alpha 2$ have been extensively studied. This report compares GB and PTX block of $\alpha 3$ GlyRs expressed in HEK 293 cells, using wholecell patch clamp techniques. In CNS, $\alpha 3$ exists as a heteropentamer in conjunction with beta subunits in a $2 \alpha: 3 \beta$ ratio. Thus, the nature of block was also tested in $\alpha 3 \beta$ heteromeric glycine receptors. GB and PTX blocked $\alpha 3$ GlyRs both in the presence (liganded state) and absence of glycine (unliganded state). This property is unique to $\alpha 3$ subunits; $\alpha 1$ and $\alpha 2$ subunits are only blocked in the liganded state. The GB block of $\alpha 3$ GlyRs is voltagedependent (more effective when the cell is depolarized) and non-competitive, while the PTX block is competitive and not voltage-dependent. The heteromeric and homomeric $\alpha 3$ GlyRs recovered significantly faster from unliganded GB block compared to liganded GB block, but no such distinction was found for PTX block suggesting more than one binding site for GB. This study sheds light on features of the $\alpha 3$ GlyR that distinguish it from the more widely studied $\alpha 1$ and $\alpha 2$ subunits. Understanding these properties can help decipher the physiological functioning of GlyRs in the CNS and may permit development of subunit specific drugs.
\end{abstract}




\section{Introduction}

Glycine receptors (GlyRs) and GABA receptors are the major fast inhibitory receptors of the central nervous system. The GlyRs are ionotropic and conduct chloride ions. These cys-loop receptors are pentameric, stoichiometrically made of two $\alpha_{1-4}$ and three $\beta$ subunits (Durisic et al., 2012). GlyR expression has been found extensively through autoradiography and immunohistochemistry techniques in the central nervous system including in the cerebellar cortex, brainstem, forebrain, retina, and hippocampus (Haverkamp et al., 2003; Crook et al., 2006; Baer et al., 2009; Xu and Gong, 2010). Despite studies on GlyR localization, deciphering the subunit composition of these receptors remains elusive. It is suggested that most GlyRs in native cells are alpha-beta heteromers; $\alpha 2$ homomeric GlyRs expression in fetal rat being the only known exception although there has been speculation that $\alpha 3$ or $\alpha 1$ GlyRs exist in homomeric form in non-somatic locations (Lynch, 2009). The $\alpha 3 \beta$ heteromers are often dominant, found in about half of the glycinergic synapses in rat retina and rat dorsal horn of the spinal cord (Haverkamp et al., 2003; Harvey et al., 2004). Relatively few studies have been conducted on $\alpha 4$ GlyRs since it is a pseudo gene in humans (Lynch, 2009) although it's expression has been shown in rat retina (Heinze et al., 2007). The unique expression of these GlyR subunits in different parts of the CNS suggests that each might have distinct functions. Thus, an important field of research is to develop tools to differentiate between the GlyRs subunits.

Our primary goal in this study was to characterize and compare the blocking action of picrotoxin (PTX) and gingkolide B (GB) on recombinant homomeric and heteromeric $\alpha 3$ GlyRs expressed in human embryonic kidney (HEK 293) cells. GB is a diterpene trilactone extracted from Gingko Biloba leaf (EGb 761). EGb 761 is widely used clinically as a treatment for neurodegeneration. GB, the most potent component of EGb 761, acts as an anticonvulsant, a platelet activating factor antagonist, and a neuroprotective agent (Maclennan et 
al., 2002). In contrast, PTX induces convulsions (Hasan et al., 2014). Yet, both block GABA and glycine receptors. Thus the mechanism of block may contribute to the opposing outcomes of these GABA/Gly antagonists. Alternatively, the selectivity of each antagonist for different receptor subtypes may explain its systemic physiology. 


\section{Materials and Methods}

Cell Culture

Human embryonic kidney cells (HEK293 cells, American Type culture collection, MD) used in the experiments were cultured in $35 \mathrm{~mm}$ plates with Dulbecco's Modified Eagle's Medium (DMEM) complete with $10 \%$ (v/v) Fetal Bovine Serum and 1\% (v/v) penicillin-streptomycin. After 24 hours they were transfected using XtremeGENE 9 DNA Transfection reagent (Roche Inc, Basel Switzerland) with either $\alpha 3$ or $\alpha 3+\beta$ cDNAs. GFP was co-transfected. A total of $2.5 \mu \mathrm{g}$ DNA were used per $35 \mathrm{~mm}$ dish with a ratio of 20:1 GlyR:GFP. When the cells were transfected with both $\alpha$ and $\beta$ subunits, they were mixed in a $10 \beta: 1 \alpha$ ratio. Cells were cultured for 18-24 hours before recording.

Electrophysiology:

Whole cell patch clamp recordings were conducted on the transfected HEK 293 cells (visually identified by green fluorescence) using Axopatch 200B amplifier and pCLAMP 9.0 software (Axon Instruments, Foster City, CA). The drugs were applied through the Octaflow II (ALA Scientific Instruments, Inc. NY) localized superfusion system. Kreb’s external solution was used in recordings, containing (in $\mathrm{mM}$ ): $140 \mathrm{NaCl}, 4.7 \mathrm{KCl}, 1.2 \mathrm{MgCl}_{2}, 2.5$ $\mathrm{CaCl}_{2}, 10$ HEPES, 10 glucose ( $\left.\mathrm{pH}=7.4\right)$. Experiments were conducted using glass pipettes pulled by a multi-step horizontal puller (Sutter Instruments, CA) and fire polished. They had a tip resistance of $\sim 5 \mathrm{M} \Omega$ and were filled with internal pipette solution containing (in $\mathrm{mM}$ ): $140 \mathrm{CsMeSO}_{4}$, 10 EGTA, 10 HEPES, 4 MgCl, 2 ATP-Mg (pH=7.2).

Glycine and picrotoxin was purchased from Sigma-Aldrich Corporation (St.Louis, MO) and Ginkgolide B from Tocris Biosciences (Bristol, UK). Glycine was dissolved in Kreb's solution to make $5 \mathrm{mM}$ solutions then further diluted to $500 \mu \mathrm{M}$. GB and PTX were dissolved in DMSO (Fisher Scientific, Waltham, MA) to make $10 \mathrm{mM}$ stock solution and 
bioRxiv preprint doi: https://doi.org/10.1101/454710; this version posted October 26, 2018. The copyright holder for this preprint (which was not certified by peer review) is the author/funder, who has granted bioRxiv a license to display the preprint in perpetuity. It is made available under aCC-BY-NC-ND 4.0 International license.

stored at 4 degree Celsius. The stock solutions were diluted with Krebs solution to the required concentrations before experiments. 


\section{Results}

\section{Glycine potency at the $\alpha 3$ GlyR}

Initial experiments indicated that the $\alpha 3$ GlyRs, both homomeric and particularly heteromeric, are much less sensitive to glycine than GlyRs containing other alpha subunits. The glycine $\mathrm{EC}_{50}$ for $\alpha 3$ homomers is $166 \mu \mathrm{M}$, compared to $99 \mu \mathrm{M}$ for $\alpha 2$ GlyRs (figure $1 \mathrm{~A}$, D). Furthermore, addition of the $\beta$ subunit raised $\mathrm{EC}_{50}$ in $\alpha 3 \beta$ to $395 \mu \mathrm{M}$ (figure $1 \mathrm{~B}$ ), while it had little effect in the $\alpha 2$ GlyR (figure $1 \mathrm{C} \& \mathrm{D}$ ). In native tissue the glycine receptor is generally expressed as a heteromer and these results indicate that $\alpha 3 \beta$ GlyRs might be distinguished by their low glycine sensitivity (figure 1E).

\section{Antagonist potency at the $\alpha 3$ GlyR}

Two antagonists of ligand-gated chloride channels, picrotoxin and ginkgolide, have been used to compare GlyR subtypes. While $\alpha 3$ GlyRs are less sensitive to glycine than other subtypes, they have comparatively high sensitivity to picrotoxin. When tested against 200 $\mu \mathrm{M}$ glycine (approximate $\mathrm{EC}_{60}$ ), the picrotoxin $\mathrm{IC}_{50}$ was $0.9 \mu \mathrm{M}$. This compares with picrotoxin $\mathrm{IC}_{50}$ at $\alpha 1$ and $\alpha 2$ homomeric GlyRs of 37.3 and $12.6 \mu \mathrm{M}$, respectively (figure 2A). Like other GlyR subtypes, addition of the $\beta$ subunit reduced the potency of picrotoxin $\left(\mathrm{IC}_{50}=11.8 \mu \mathrm{M}\right.$ tested against the $\mathrm{EC}_{60}$ of glycine which is $468 \mu \mathrm{M}$, figure $2 \mathrm{~B}$ ).

Ginkgolide B potency at the $\alpha 3$ GlyR was less than reported at $\alpha 1$ or $\alpha 2$ GlyRs, but like these other receptors the block was better in the heteromeric receptor (figure 2C). The $\mathrm{GB} \mathrm{IC}_{50}$ is $17 \mu \mathrm{M}$ in the $\alpha 3$ homomeric and $7 \mu \mathrm{M}$ in the $\alpha 3 \beta$ heteromeric receptor. There is also a change in the Hill coefficient, from approximately 2 to 1 . In comparison with $\alpha 1$ and $\alpha 2$ GlyRs, the relatively high potency of picrotoxin and low potency of ginkgolide B might be used to distinguish the $\alpha 3 \beta$ GlyR. 
$\underline{\text { GB is a non-competitive blocker and PTX is a competitive blocker of alpha } 3 \text { GlyRs }}$

Studies have shown that GB is a non-competitive blocker of native GlyRs in hippocampal pyramidal rat neurons as well as in $\alpha 1$ and $\alpha 2$ GlyRs (Kondratskaya et al., 2004;

Kondratskaya et al., 2005; Hawthorne et al., 2006a). In contrast, PTX is a competitive blocker in $\alpha 1$ and $\alpha 2$ GlyRs (Lynch et al., 1995; Wang et al., 2006). We tested GB and PTX block in $\alpha 3$ and $\alpha 3 \beta$ GlyRs.

The peak current response $\left(\mathrm{I}_{0}\right)$ to application of $500 \mu \mathrm{M}$ or $5 \mathrm{mM}$ glycine was recorded and compared to the peak response in the presence of the antagonist (I), with either $2 \mu \mathrm{M}$ PTX or $1 \mu \mathrm{M}$ GB in cells held at $-50 \mathrm{mV}$ (figure 3 ). In 8 cells expressing homomeric $\alpha 3$ GlyR subunits, $1 \mu \mathrm{M}$ GB on average blocked $12 \pm 9 \%$ of $500 \mu \mathrm{M}$ glycine-induced current and $9 \pm 5 \%$ of $5 \mathrm{mM}$ glycine-induced current (Figure $3 \mathrm{~A}$ ). There was no statistically significant difference between the two blocks, indicative of non-competitive inhibition. In contrast, 2 $\mu \mathrm{M}$ PTX blocked $43 \pm 9 \%$ of the $500 \mu \mathrm{M}$, but only $16 \pm 10 \%$ of $5 \mathrm{mM}$ glycine-induced current. This difference in fractional block was statistically significant $(\mathrm{p}<0.01)$, suggesting that PTX is a competitive blocker.

In heteromeric $\alpha 3 \beta$ GlyR, there was no significant difference in the block of $500 \mu \mathrm{M}$ or 5 mM glycine produced by $1 \mu \mathrm{M} \mathrm{GB}$, but $10 \mu \mathrm{M}$ PTX produced a greater block of $500 \mu \mathrm{M}$ than $5 \mathrm{mM}$ glycine (Figure 3B). $1 \mu \mathrm{M}$ GB blocked $21 \pm 13 \%$ of $500 \mu \mathrm{M}$ and $12 \pm 7 \%$ of $5 \mathrm{mM}$ glycine-induced current. But $10 \mu \mathrm{M}$ PTX blocked $65 \pm 6 \%$ of $500 \mu \mathrm{M}$ and only $16 \pm 10 \%$ of 5 mM glycine-induced current. Higher PTX concentrations were used in the experiments on heteromeric receptors because they are less sensitive than the homomeric glycine receptor (see figure 2). Overall, block of $\alpha 3$-containing GlyRs by picrotoxin and ginkgolide B show the same competitive/non-competitive differences seen in the $\alpha 1$ and $\alpha 2$ containing GlyRs. 


\section{GB block is voltage sensitive in alpha 3 GlyR}

We tested the voltage sensitivity of GB and PTX block in homomeric and heteromeric $\alpha 3$ GlyR. Two measurements were taken during a $10 \mathrm{~s}$ application of $500 \mu \mathrm{M}$ Glycine + antagonist: first the block of peak current and then after $5.5 \mathrm{sec}$. These responses were compared to the peak of the initial glycine current without antagonist (only the currents in the presence of antagonists are shown in figure 4). For homomeric $\alpha 3$ GlyRs, the measurements were taken at $-10 \mathrm{mV}$ and $-50 \mathrm{mV}$, which were on either side of the reversal potential of -30 $\mathrm{mV}$. A high concentration of GB $(100 \mu \mathrm{M})$ was used in $\alpha 3$ GlyRs because of its comparatively low potency (Figure 4)

In $\alpha 3$ GlyRs the action of GB was voltage sensitive. GB blocked $58 \pm 14 \%$ of the glycine current at $-50 \mathrm{mV}$ in contrast to $81 \pm 5 \%$ at $-10 \mathrm{mV}$. After $5.5 \mathrm{sec}$, GB blocked $75 \pm 15 \%$ at -50 $\mathrm{mV}$ and $98 \pm 2 \%$ at $-10 \mathrm{mV}$ (figure 4 , top). Thus, at both time points $\alpha 3$ GlyRs were blocked significantly better at $-10 \mathrm{mV}$ compared to $-50 \mathrm{mV}(\mathrm{p}<0.001)$. This finding is consistent with studies in rat hippocampal pyramidal neurons (Kondratskaya et al., 2002). Top right of Figure 4 shows sample traces of $10 \mathrm{~s}$ application of $500 \mu \mathrm{M}$ Gly $+100 \mu \mathrm{M}$ GB at the two voltages. The control glycine trace, without antagonist, is not shown because the control peak was of equal magnitude at both voltages. The histogram at top left summarizes the voltage sensitive block by GB of the peak current and the current after 5.5 seconds.

In $\alpha 2$, PTX is not a voltage sensitive blocker (Wang et al., 2006). In order to test how PTX behaves in $\alpha 3$, we used the same protocol employed for GB. At block peak, $2 \mu \mathrm{M}$ PTX blocked $55 \pm 11 \%$ of the current evoked by $500 \mu \mathrm{M}$ Gly at $-10 \mathrm{mV}$ and $52 \pm 13 \%$ at $-50 \mathrm{mV}$.

Since the differences in blocks are not significant, we conclude that PTX is not a voltage sensitive blocker in $\alpha 3$ GlyRs (data not shown).

Similar experiments were repeated on $\alpha 3 \beta$ GlyRs, but using a lower GB $(1 \mu \mathrm{M})$ concentration because of its greater potency in the heteromers. Here we made the 
measurements at $-10 \mathrm{mV},-50 \mathrm{mV}$ and $-90 \mathrm{mV}$. At $-50 \mathrm{mV}$ and $-10 \mathrm{mV}$ this batch of cells showed outward current, so we also tested at $-90 \mathrm{mV}$, where an inward current was evoked.

In $\alpha 3 \beta$ GlyRs, GB blocked $25 \pm 8 \%$ of $500 \mu \mathrm{M}$ Gly induced peak current at $-10 \mathrm{mV}$, compared to $10 \pm 4 \%$ at $-90 \mathrm{mV}$ and $11 \pm 4 \%$ at $-50 \mathrm{mV}$. Thus, like homomeric $\alpha 3$ GlyRs, there was a significantly better GB block at $-10 \mathrm{mV}$ in $\alpha 3 \beta$ GlyRs. Since there was almost no difference between $-90 \mathrm{mV}$ and $-50 \mathrm{mV}$ block, we conclude that direction of ion flow is not an important factor in GB block. There was not a statistically significant difference in block at the two voltages after $5.5 \mathrm{~s}$. GB block of glycine in $\alpha 3 \beta$ GlyRs was $61 \pm 16 \%$ at $-10 \mathrm{mV}$, $53 \pm 15 \%$ at $-90 \mathrm{mV}$, and $50 \pm 16 \%$ at $-50 \mathrm{mV}$. The right panel of Figure $4 \mathrm{~B}$ shows sample traces and the left panel shows a summary of the data at $-10 \mathrm{mV}$ and $-90 \mathrm{mV}$. Difference in the rate of desensitization in $\alpha 3 \beta$ and $\alpha 3$ GlyRs is a potential reason for the lack of voltage sensitivity after $5.5 \mathrm{~s}$ in $\alpha 3 \beta$.

The $\alpha 3 \beta$ GlyRs showed no statistically significant difference in PTX block at $-10 \mathrm{mV},-50$ $\mathrm{mV}$ and $-90 \mathrm{mV}$. At the peak of the glycine current, PTX blocked $30 \pm 13 \%$ at $-10 \mathrm{mV}$, $30 \pm 13 \%$ at $-50 \mathrm{mV}$ and $38 \pm 15 \%$ at $-90 \mathrm{mV}$.

\section{Differences from other GlyRs}

a. Pre-treatment with GB and PTX blocks $\alpha 3$ GlyR currents

Both GB and PTX are thought to block the channel pore. Many pore blockers are usedependent because they require the agonist to open the pore to allow access to the blocker. Hence, two blocking mechanisms were compared: 1) Liganded or use-dependent block that occurs when glycine and antagonist are applied together and 2) Unliganded or non-usedependent block in which the action of the antagonist does not depend on the presence of the agonist. PTX block has been linked to amino acids in the glycine channel pore but has been shown to be non-use dependent in $\alpha 1$ (Lynch et al., 1995), but use-dependent in $\alpha 2$ (Wang et 
al., 2006). GB has been proposed to block in a use-dependent manner in native hippocampal neuron (Kondratskaya et al., 2002) and in $\alpha 2$ GlyRs (Hawthorne et al., 2006a). In our experiments, the protocol used to test for unliganded block was to: 1) apply $500 \mu \mathrm{M}$ glycine for $2 \mathrm{~s}$ (first glycine response), wait for the current to return to baseline, and then 2) apply antagonist GB or PTX (without glycine) for $10 \mathrm{~s}$ and then after a wash period of $3 \mathrm{~s}, 3$ ) apply only $500 \mu \mathrm{M}$ glycine for $2 \mathrm{~s}$ (second glycine response). If the antagonist blocked the unliganded receptor, then the second glycine peak would be reduced. To test for liganded block: 1) $500 \mu \mathrm{M}$ glycine was first applied for $2 \mathrm{~s}$ (first glycine response) then after recovery to baseline 2) GB or PTX was co-applied with $500 \mu \mathrm{M}$ glycine for $10 \mathrm{~s}$, followed by a $3 \mathrm{~s}$ wash and then 3) $500 \mu \mathrm{M}$ glycine (without antagonist) was reapplied for $2 \mathrm{~s}$ (second glycine peak). The results are expressed as the percentage of control peak glycine current that was blocked $\left(\frac{I_{0}-I}{I_{0}} x 100 \%\right)$.

An example of this protocol is shown in Figure 5. The experiment was performed on $\alpha 3$ homomers and PTX fully blocked the effect of concomitantly applied glycine (top trace). After washout of both drugs, brief reapplication of glycine caused progressively larger currents, indicating a slow removal of the bound PTX block. When this protocol was repeated with the application of PTX alone (bottom trace) there was a similar slow unblocking. Thus, regardless of whether PTX was applied in the presence (liganded) or absence (unliganded) of glycine, PTX produced a similar level of block. Each of the secondary glycine applications represents a new sequence of the three steps and all sequences shown were performed in the same cell. The results indicate that, like the $\alpha 1$ and $\alpha 2$ GlyRs, PTX block of the $\alpha 3$ homomer was not use-dependent.

To test the validity of our experimental protocol, we compared the GB liganded and unliganded block of $\alpha 2$ GlyRs, using the protocol shown in figure 5 (Figure 6, top left). The first pair of superimposed traces shows that glycine alone (black) and glycine after 
pretreatment with GB (gray) produced similar currents. There was no evidence of $\alpha 2$ GlyR inhibition in the unliganded-block protocol. In contrast, $\sim 27 \%$ of $\alpha 2$ GlyRs were blocked in liganded receptors. This experiment agrees with studies indicating that $\alpha 2$ GlyRs show only liganded block and also supports our experimental design.

Surprisingly, GB blocked unliganded $\alpha 3$ GlyRs and this block showed voltage dependence similar to the liganded receptor block (Figure 6, top right). Each superimposed pair of current traces in Figure 6 shows the response to glycine alone in black and the second glycine current, 3s after GB removal, in gray. The bar graph below each pair of superimposed traces shows the fractional remaining current in the step 3 protocol for all cells tested. The first two sets of superimposed traces in Figure 6 top right show that, for cells held at $-10 \mathrm{mV}$, GB blocks on average $61 \pm 11 \%$ of the unliganded receptor after $3 \mathrm{~s}$ and $65 \pm 5 \%$ of the liganded receptor. The middle two traces show that GB is less effective in cells held at $-50 \mathrm{mV}$, where the unliganded block is $20 \pm 5 \%$ and the liganded block is $34 \pm 5 \%$. Thus, GB could bind and block the closed channel. PTX could also bind to the closed, unliganded $\alpha 3$ GlyR as shown in the last two pair of superimposed traces. In the unliganded protocol, $55 \pm 9 \%$ of the current remained blocked by PTX after 3s, (measurements only conducted at $-50 \mathrm{mV}$ since PTX block is not voltage sensitive). PTX blocked $44 \pm 11 \%$ of the GlyR current in the liganded receptor. In all three sets of responses there was no statistically significant difference in the fraction of block produced in the liganded vs the unliganded state.

These experiments were repeated in the heteromeric GlyR, but drug concentrations were $500 \mu \mathrm{M}$ glycine, $1 \mu \mathrm{M}$ GB and $10 \mu \mathrm{M}$ PTX, because the heteromeric receptor was more sensitive to GB and less to PTX and glycine (Figure 6, lower panel). These receptors were also found to be blocked in unliganded and liganded state by PTX and GB. Again, we tested $\alpha 3 \beta$ GlyRs at $-10 \mathrm{mV},-50 \mathrm{mV}$ (not shown) and $-90 \mathrm{mV}$ to examine whether direction of ion flow has any effect on recovery. At $-10 \mathrm{mV}$ and $-50 \mathrm{mV}$ the currents were outward and at -90 
$\mathrm{mV}$ the current was inward. For the unliganded receptor, the remaining GB block after 3s was $29 \pm 13 \%$ at $-10 \mathrm{mV}, 40 \pm 15 \%$ at $-50 \mathrm{mV}$ and $36 \pm 14 \%$ at $-90 \mathrm{mV}$. When these receptors were tested in the liganded state, the GB block was $61 \pm 16 \%$ at $-10 \mathrm{mV}$ and $40 \pm 9 \%$ at both -90 $\mathrm{mV}$ and at $-50 \mathrm{mV}$. The liganded PTX block after $3 \mathrm{~s}$ was $36 \pm 11 \%$, measured at $-90 \mathrm{mV}$ holding potential.

The $\alpha 3$ homomeric and heteromeric glycine receptors are blocked in the unliganded and liganded state by GB and PTX. Only $-10 \mathrm{mV}$ and $-90 \mathrm{mV}$ GB blocks are shown in figure 7 because there were no differences between GB blocks at $-50 \mathrm{mV}$ vs $-90 \mathrm{mV}$. Thus, it follows that direction of ion flow does not affect recovery. Based on these results, the next set of experiments were conducted at $-10 \mathrm{mV}$ and at $-90 \mathrm{mV}$.

\section{Recovery Rate from Liganded and Unliganded block}

Next, we compared the rate of recovery of the GlyRs from the liganded and unliganded block described above. The same drug concentrations were used (i.e, $500 \mu \mathrm{M}$ Glycine, $100 \mu \mathrm{M}$ GB, $1 \mathrm{mM}$ PTX for $\alpha 3$ and $500 \mu \mathrm{M}$ Glycine, $1 \mu \mathrm{M}$ GB and $10 \mu \mathrm{M}$ PTX for $\alpha 3 \beta)$ but the wash time was prolonged to $10 \mathrm{~s}$. The results express GB or PTX block remaining after $10 \mathrm{~s}$ wash. Note that the peak of the second glycine current after $10 \mathrm{sec}$ includes recovery from both block and desensitization. Preliminary experiments, without antagonists, indicated that recovery from desensitization was complete at $3 \mathrm{~s}$. However, it is unclear if antagonists will affect this rate of recovery from desensitization, so the recovered current of the second glycine peak may not only measure of antagonist unbinding.

At $-10 \mathrm{mV}$, homomeric $\alpha 3$ GlyRs recovered faster from GB unliganded block compared to GB liganded block (Figure $8 \mathrm{~A}$ ). There was a $30 \pm 12 \%$ block remaining in the liganded condition after $10 \mathrm{~s}$ and the receptors fully recovered in $\sim 60 \mathrm{~s}$. Unliganded GB block fully recovered in $10 \mathrm{sec}$. There were no significant difference in recovery after $10 \mathrm{~s}$ of liganded and unliganded blocks with GB at $-50 \mathrm{mV}$ or for PTX at $-50 \mathrm{mV}$. After $10 \mathrm{~s}$ wash, 
at $-50 \mathrm{mV}$, about $17 \pm 17 \%$ block remained in unliganded GB condition and about $28 \pm 11 \%$ block remained in liganded GB condition. Similarly, block remaining $10 \mathrm{~s}$ after unliganded PTX treatment was $28 \pm 9 \%$ and after liganded PTX was $23 \pm 11 \%$.

A similar trend was found in $\alpha 3 \beta$ heteromers. As shown in Figure $8 B$, liganded GB block at $-10 \mathrm{mV}$ produced a $34 \pm 17 \%$ block after 10 s wash while only $5 \pm 5 \%$ block remained 10s after unliganded GB block at $-10 \mathrm{mV}$. No significant difference between recovery from liganded and unliganded block was found with GB at $-90 \mathrm{mV}$ or with PTX. At $-90 \mathrm{mV}$, block remaining 10s after liganded GB block was $15 \pm 7 \%$ and after unliganded GB block was $22 \pm 9 \%$. And $20 \pm 17 \%$ block remained 10 s after liganded PTX block and $12 \pm 7 \%$ block remained after unliganded PTX block.

These results suggest mechanistic differences between GB block of the glycine bound and glycine free receptor. It is possible that there is more than one voltage sensitive binding site for GB. For simplicity if we assume there are two sites, one site is accessible in the liganded or unliganded state and the other site is only accessible when glycine is present. At holding potential of $-10 \mathrm{mV}$, GB is bound efficiently to the second site and dissociates more slowly compared to the same liganded receptors at more negative voltages or to unliganded receptors at $-10 \mathrm{mV}$. 


\section{Discussion}

\section{Distinct Pharmacology of $\alpha 3$ GlyR}

This study reveals a number of unique features conferred by the $\alpha 3$ subunit of the glycine receptor. It is relatively insensitive to glycine, the heteromeric $\alpha 3 \beta$ receptor $\mathrm{EC}_{50}$ is close to $400 \mu \mathrm{M}$. This is almost an order of magnitude less sensitive than heteromeric $\alpha 1$ GlyRs. The $\beta$ subunit contributes to this low glycine sensitivity, which is unusual in that the $\beta$ subunit of $\alpha 1$ or $\alpha 2$ GlyRs has little effect on sensitivity. The low glycine sensitivity might expand the dynamic range of the glycine response, since the $\alpha 3$-containing receptor can respond to glycine levels that have saturated the other GlyR types.

Another interesting property of the $\alpha 3$ GlyR is the high sensitivity to picrotoxin. With an $\mathrm{IC}_{50}$ of $\sim 1 \mu \mathrm{M}$, the homomeric $\alpha 3$ GlyR is as sensitive, or more sensitive, than GABA receptors. The $\alpha 3 \beta$ GlyR has an PTX $\mathrm{IC}_{50}$ of $\sim 12 \mu \mathrm{M}$, which is still close to that of GABA receptors. This indicates that PTX does not uniquely identify GABA receptors in pharmacological experiments and adds to the questionable utility of PTX based on studies of $\alpha 2$ GlyRs.

PTX Block of $\alpha 3$ GlyR

Mechanism of PTX inhibition in ligand-gated ion channels has not been fully elucidated. A single mutation in M2 reduces PTX sensitivity in GABA and glycine receptors (Pribilla et al., 1992; Zhang et al., 1995). The ring of threonines in the 6' position is associated with PTX sensitivity in GABA, 5-HT3 (Gurley et al., 1995; Das and Dillon, 2005) and glycine receptors (Shan et al., 2001a; Hawthorne and Lynch, 2005), which suggests a pore binding model for PTX. However, PTX inhibition is competitive and voltage insensitive (Lynch et al., 1995; Wang et al., 2006) which are inconsistent with a pore blocker. This has led to an allosteric model of PTX inhibition (Lynch et al., 1995; Shan et al., 2001a). PTX is 
competitive, not use-dependent, and voltage insensitive in $\alpha 3$ GlyRs. Furthermore, recovery rate of $\alpha 3$ GlyR from liganded and unliganded block by PTX is indistinguishable. Thus, PTX binding site in $\alpha 3$ GlyRs is in a region that is freely accessible in both open and closed state of the receptor. Glycine is not necessary for the $\alpha 3$ GlyR to recover from liganded block, which argues against the trap mechanism that is proposed in $\alpha 2$ GlyRs (Wang et al., 2006) and $\alpha 1$ GlyRs (Hawthorne and Lynch, 2005).

\section{Comparison of PTX and GB at $\alpha 3$ GlyR}

PTX and GB have similarities in molecular structure (Ivic et al., 2003a) and are both thought to bind near the pore region of the channel (Hawthorne et al., 2006b; Heads et al., 2008b). Support for this comes from mutations of T6, an amino acid in the middle of the M2 transmembrane segment, that reduce the effectiveness of PTX and GB (Shan et al., 2001b; Hawthorne et al., 2006b). In our experiments the potency of GB was similar to PTX, although repeated exposure can increase the apparent potency of a use-dependent ligand. The heteromer is more sensitive to GB and less sensitive to PTX, which is also true in $\alpha 2 \beta$ GlyRs. The most distinctive differences between the two antagonists is that GB is voltage-dependent and non-competitive. These are properties that the $\alpha 3$ GlyR shares with the $\alpha 2$ receptor. In heterologously expressed $\alpha 2$ GlyRs, and in native rat hippocampal neurons, GB potency does not depend on the glycine concentration but is less effective when the cell is hyperpolarized. These two properties, along with use-dependence, are hallmarks of pore blockers.

But GB block at $\alpha 3$ GlyRs is not exclusively use-dependent; GB can bind and block the unliganded, closed state of the receptor. This is unlike GB's effect in hippocampal pyramidal cells or in heterologously expressed $\alpha 2$ GlyRs and does not fit with the classic pore blocker model which acts only on open channels. 
Although $\alpha 1$ GlyRs has been reported to be blocked in unliganded state by PTX, none of the other receptors are blocked by either antagonist in the unliganded state. The unique antagonism profile of $\alpha 3$ GlyRs may help in pharmacologically identifying the subunit composition in native neurons.

Most studies agree that homomeric $\alpha 3$ GlyRs are not expressed in somatic regions of adult neurons (Lynch, 2009), but may be present in presynaptic nerve terminals of adult auditory brainstem neurons (Turecek and Trussell, 2002) and neurons of rat supraoptic nucleus (Deleuze et al., 2005).The $\alpha 3 \beta$ GlyRs were seen in the inner plexiform layer of the retina and dorsal horn of the spinal cord neurons using immunohistochemistry (Haverkamp et al., 2003; Harvey et al., 2004), but these findings need validation (Elliott et al., 2015). Use of GB and PTX as pharmacological tools can help provide further support for this identification. $\alpha 3$ GlyRs have been implicated in tactile allodynia (Huang et al., 2017) and Glra3 ${ }^{-/-}$knockout mice have reduced prostaglandin E2 induced pain sensitization. (Harvey et al., 2004). These findings identify $\alpha 3$ GlyRs as molecular pain target and since GB and PTX block $\alpha 3 \beta$ GlyRs, they might be useful in pain therapy if their action can be localized.

We sought to compare PTX antagonism with GB antagonism in $\alpha 3$ GlyRs due to the postulated structural similarity between the two compounds (Ivic et al., 2003b). Although the mechanism of GB inhibition is unresolved, there is evidence that GB binds to the 2'-6' pore lining region of the M2 transmembrane segment of GlyRs (Kondratskaya et al., 2005; Hawthorne et al., 2006a; Heads et al., 2008a). This is further supported by the noncompetitive, use-dependent and voltage sensitive nature of the block (Kondratskaya et al., 2002; Kondratskaya et al., 2004; Kondratskaya et al., 2005; Hawthorne et al., 2006a). In addition to non-competitive, voltage sensitive and use-dependent properties, our data show an unliganded GB block in $\alpha 3$ GlyRs. We have also shown that recovery from the liganded block is slower than the unliganded block. These data might be explained by two GB binding 
sites in the $\alpha 3$ GlyR. Site 1 is outside the pore and responsible for unliganded block. It can even be in the extracellular domain since a recent study identifies a novel allosteric site above the glycine binding site (Huang et al., 2004). Site 2 is in the pore and accessible only when the channel is open. Recovery from liganded GB block requires GB to fall off from both Sites 1 and 2 and hence takes longer than unliganded recovery. Either or both of these sites can be voltage sensitive. A similar competitive, unliganded inhibition of $\rho 1$ GABA $\mathrm{C}$ receptors by GB has been reported (Huang et al., 2012) and they also suggested the possibility of two ginkgolide binding sites. The apparent competitive inhibition in $\mathrm{GABA}_{\mathrm{C}}$ receptors may be due to an allosteric effect on agonist binding rather than a physical competition for the binding site.

Acknowledgement: The work was funded by National Eye Institute grant to M.M.S. S.C. was supported by scholarships from University at Buffalo. 


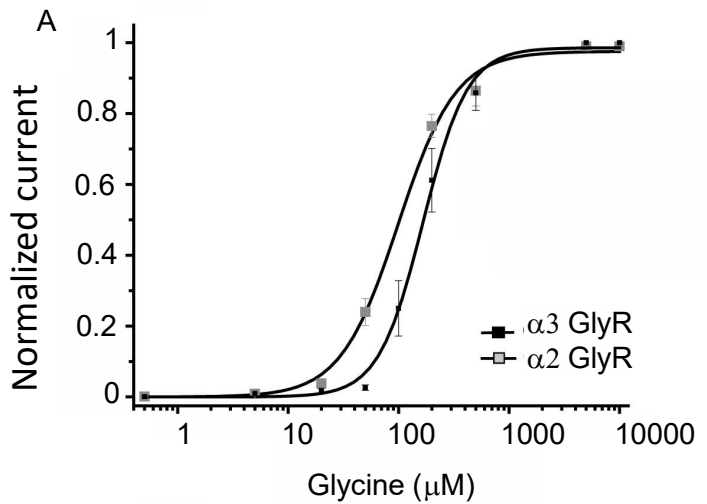

C
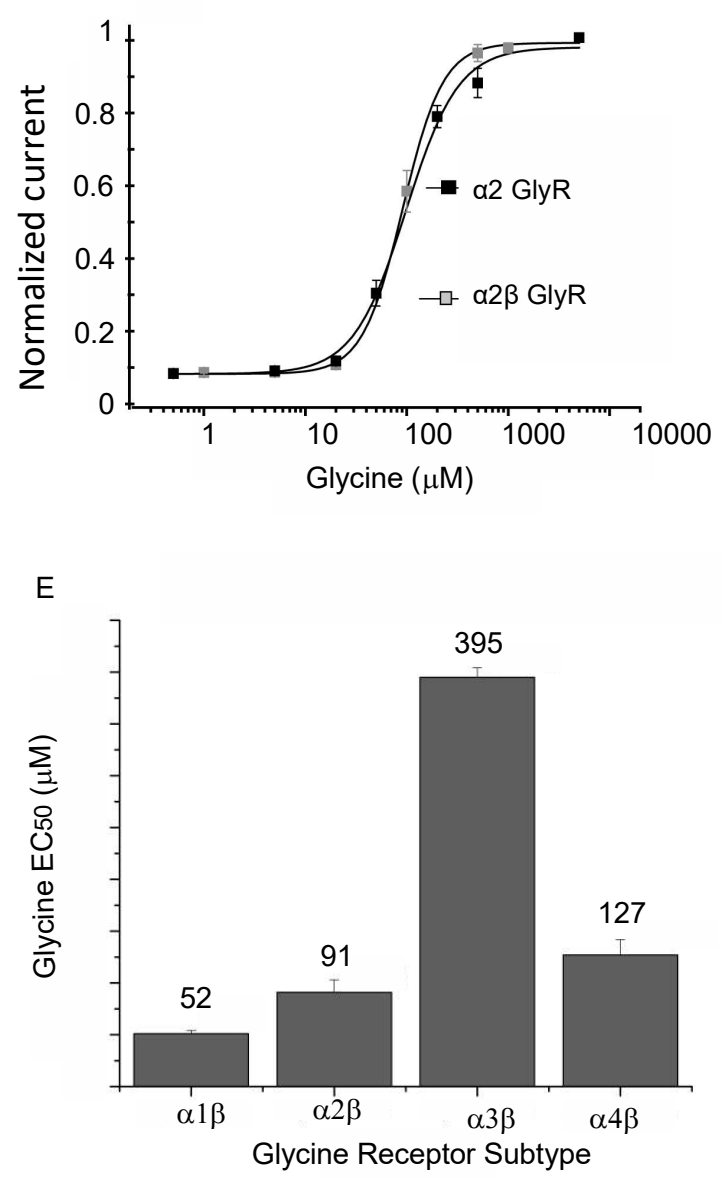

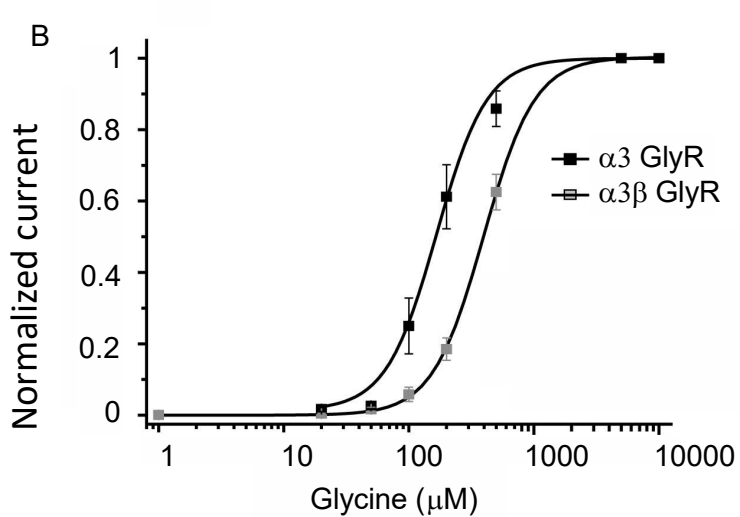

D

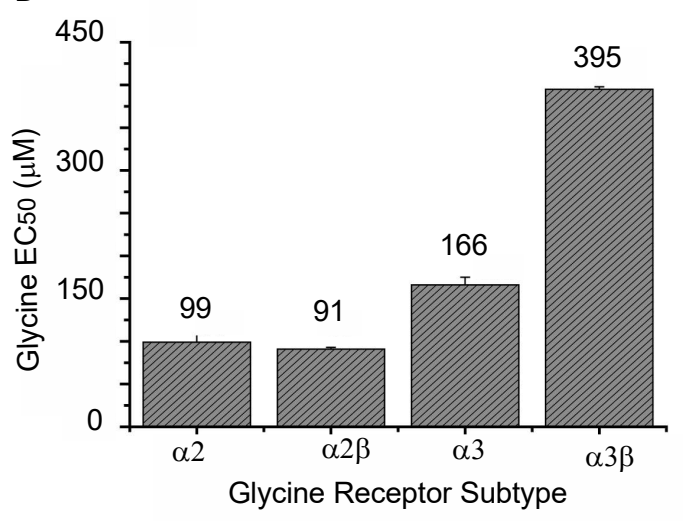

Figure 1: Comparative agonist sensitivity of the alpha subunits in glycine receptors. A)

Relative response of homomeric alpha2 and alpha3 GlyRs. B) Glycine-elicited response in homomeric and heteromeric alpha3 GlyRs. C) Response of alpha2 homomeric and 
bioRxiv preprint doi: https://doi.org/10.1101/454710; this version posted October 26, 2018. The copyright holder for this preprint (which was not certified by peer review) is the author/funder, who has granted bioRxiv a license to display the preprint in perpetuity. It is made available under aCC-BY-NC-ND 4.0 International license.

heteromeric GlyRs. D) EC50 values of homomeric and heteromeric alpha2 and alpha3

GlyRs. E) Comparison of mean EC50 values of various heteromeric GlyRs. 


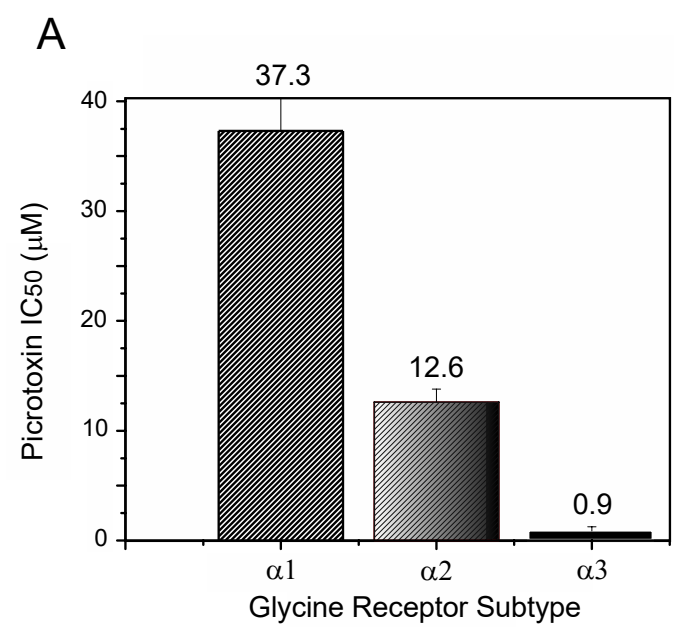

B
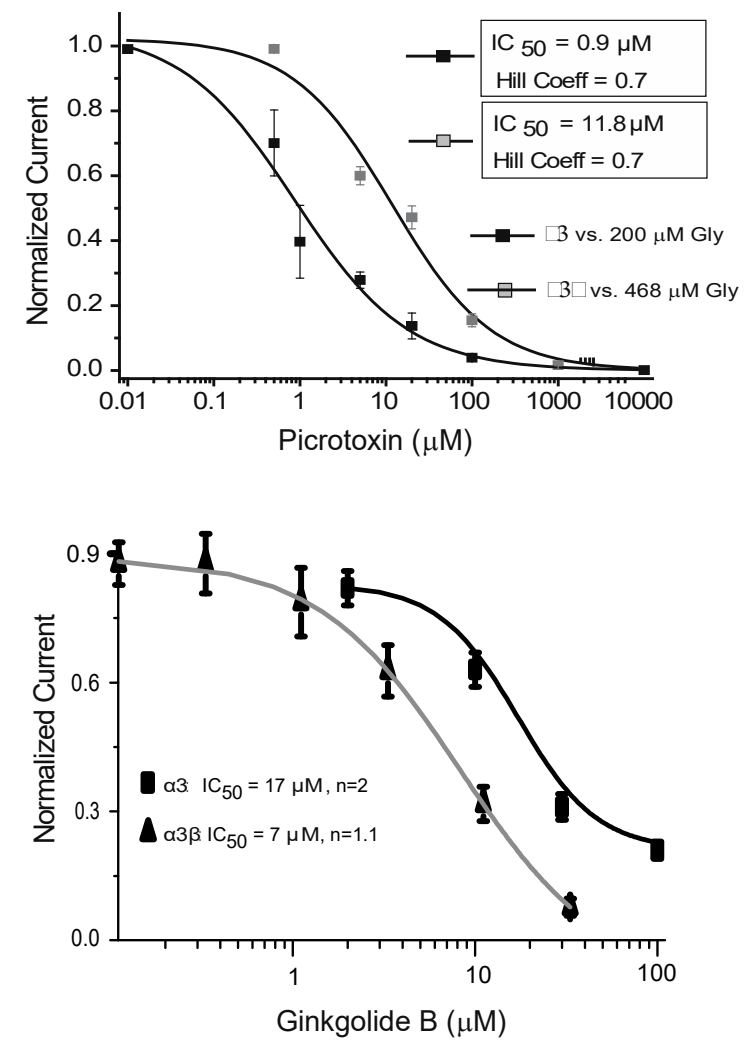

Figure 2 Antagonist effectiveness at GlyRs. A) Comparison of the IC50 values of picrotoxin block of glycine for homomeric GlyRs (see text for detailed description). B) Comparison of picrotoxin block of glycine activity in homomeric and heteromeric alpha3 GlyRs. C) Block of $500 \mathrm{uM}$ glycine by ginkgolide in homomeric and heteromeric alpha3 GlyRs. 

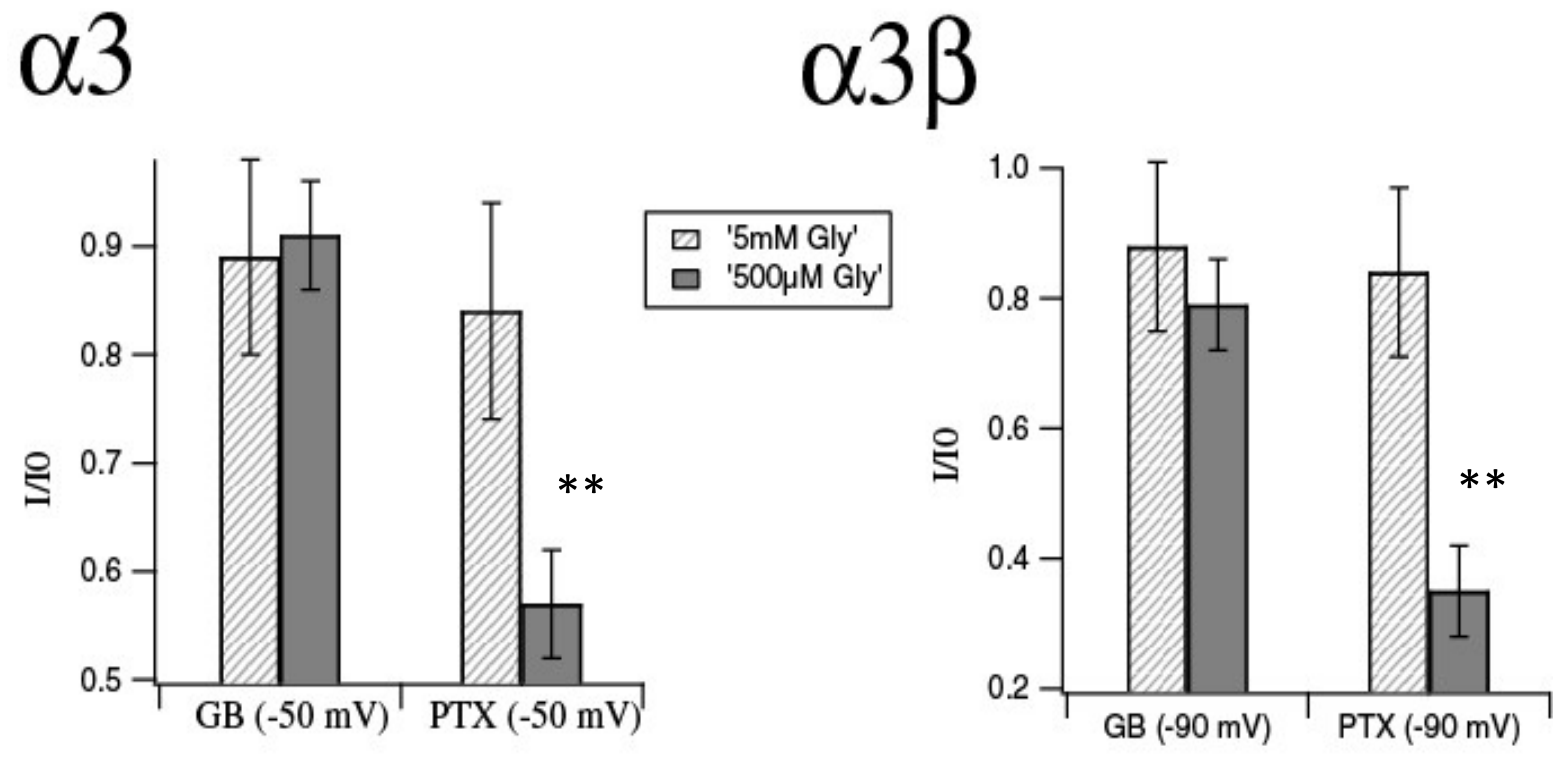

Figure 3: Picrotoxin is a competitive antagonist, GB is non-competitive. In the bar graphs, dashed bars represent $\mathrm{I} / \mathrm{I}_{0}$ (where $\mathrm{I}$ is the peak glycine current in the presence of the antagonist and $\mathrm{I}_{0}$ is the peak current in glycine alone) for $5 \mathrm{mM}$ gly and solid bars represent $\mathrm{I} / \mathrm{I}_{0}$ for $500 \mu \mathrm{M}$ Gly. In $\alpha 3$ GlyR (left graph), blocking effects of $1 \mu \mathrm{M}$ GB and $2 \mu \mathrm{M}$ PTX were recorded at $-50 \mathrm{mV}$. With GB, I/I $\mathrm{I}_{0}(5 \mathrm{mM}$ Gly $)=0.91 \pm 0.05, \mathrm{n}=8$ and $\mathrm{I} / \mathrm{I}_{0}(500 \mu \mathrm{M}$ Gly $)$ $=0.88 \pm 0.09, \mathrm{n}=8$. With PTX, $\mathrm{I} / \mathrm{I}_{0}(5 \mathrm{mM}$ Gly $)=0.84 \pm 0.10, \mathrm{n}=8$ and $\mathrm{I} / \mathrm{I}_{0}(500 \mu \mathrm{M}$ Gly $)=$ $0.57 \pm 0.09, \mathrm{n}=8$. The second graph shows the effect of $1 \mu \mathrm{M}$ GB and $10 \mu \mathrm{M}$ PTX on $\alpha 3 \beta$ GlyR at $-90 \mathrm{mV}$. With GB, I/I $\mathrm{I}_{0}(5 \mathrm{mM}$ Gly $)=0.88 \pm 0.07, \mathrm{n}=8$ and $\mathrm{I} / \mathrm{I}_{0}(500 \mu \mathrm{M}$ Gly $)=$ $0.79 \pm 0.13, \mathrm{n}=10$. With PTX, $\mathrm{I} / \mathrm{I}_{0}(5 \mathrm{mM}$ Gly $)=0.84 \pm 0.10, \mathrm{n}=5$ and $\mathrm{I} / \mathrm{I}_{0}(500 \mu \mathrm{M}$ Gly $)=$ $0.35 \pm 0.06, \mathrm{n}=5$. 

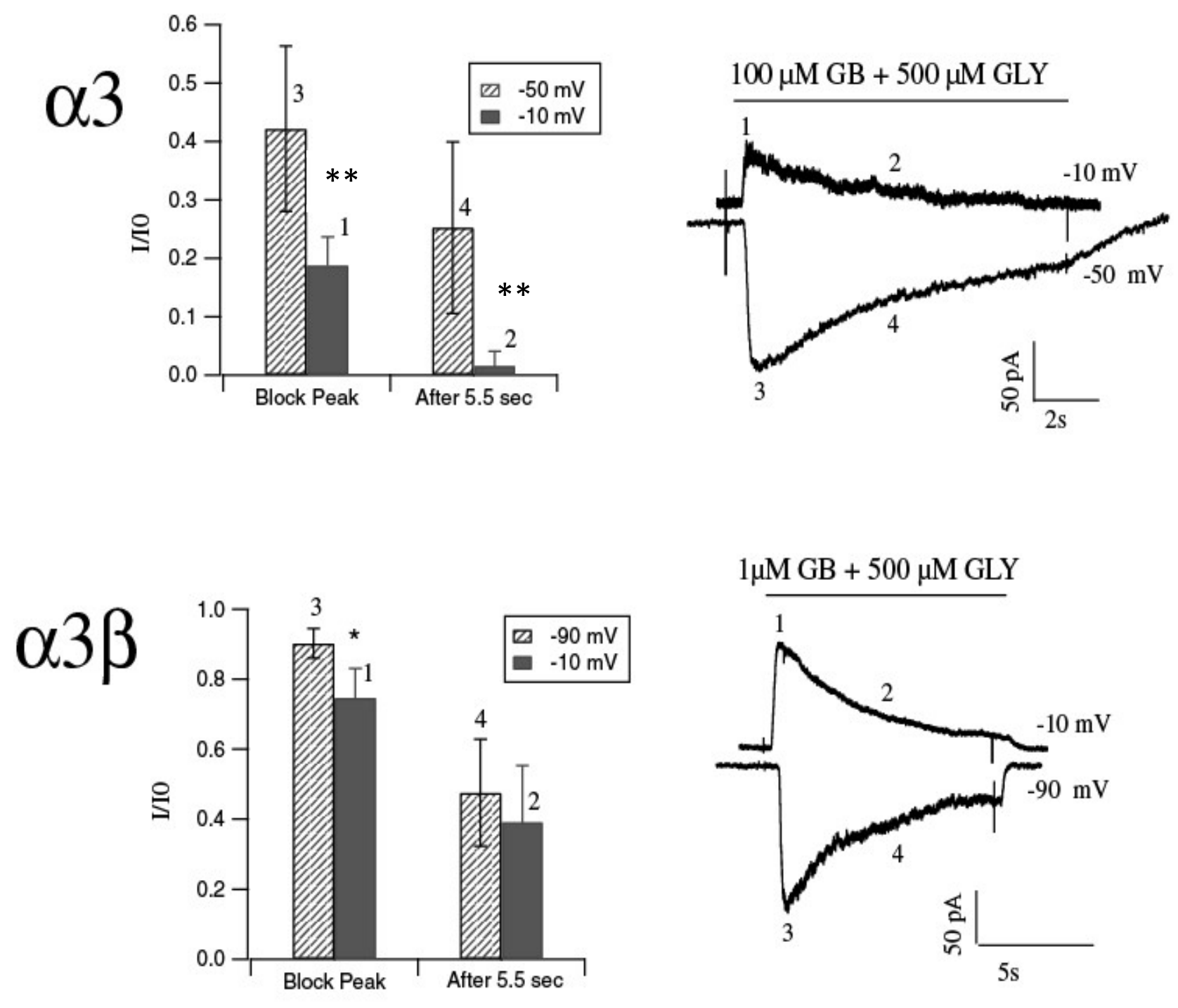

Figure 4: GB block is voltage-dependent in $\alpha 3$ GlyRs. Points marked 1,2,3 and 4 in the bar graph (left) correspond to the time points marked in the raw traces (right). The bar graph depicts $I / I_{0}$ where $I_{0}$ is the control $500 \mu \mathrm{M}$ Glycine trace (not shown in raw trace).

Top panel - Voltage sensitive GB block in $\alpha 3$ GlyRs - Points 1 and 3 are block of peak currents at $-10 \mathrm{mV}$ and $-50 \mathrm{mV}$ respectively. $\mathrm{I} / \mathrm{I}_{0}$ values for the points marked 1 and 3 in the bar graph are $0.42 \pm 0.14, \mathrm{n}=13$ and $0.19 \pm 0.05, \mathrm{n}=17$. Points 2 and 4 are GB block after 5.5 sec 
at $-10 \mathrm{mV}$ and $-50 \mathrm{mV}$ respectively. $\mathrm{I} / \mathrm{I}_{0}$ value for point 2 is $0.02 \pm 0.02, \mathrm{n}=17$ and for point 4 is $0.25 \pm 0.15, \mathrm{n}=13$. The peak of the control glycine current was same at $-10 \mathrm{mV}$ and $-50 \mathrm{mV}$. Bottom Panel - Voltage sensitive GB block in $\alpha 3 \beta$ GlyRs - Points 1 and 3 are block of peak currents at $-10 \mathrm{mV}$ and $-90 \mathrm{mV}$ respectively. $\mathrm{I} / \mathrm{I}_{0}$ value at point 1 is $0.75 \pm 0.08, \mathrm{n}=9$ and at point 3 is $0.90 \pm 0.04, \mathrm{n}=7$. Points 2 and 4 are GB block after $5.5 \mathrm{sec}$ at $-10 \mathrm{mV}$ and $-90 \mathrm{mV}$ respectively. $\mathrm{I} / \mathrm{I}_{0}$ value for point 2 is $0.39 \pm 0.16, \mathrm{n}=9$ and for point 4 is $0.47 \pm 0.15, \mathrm{n}=7$. 


\section{PTX block of liganded $\alpha 3$ GLYR}

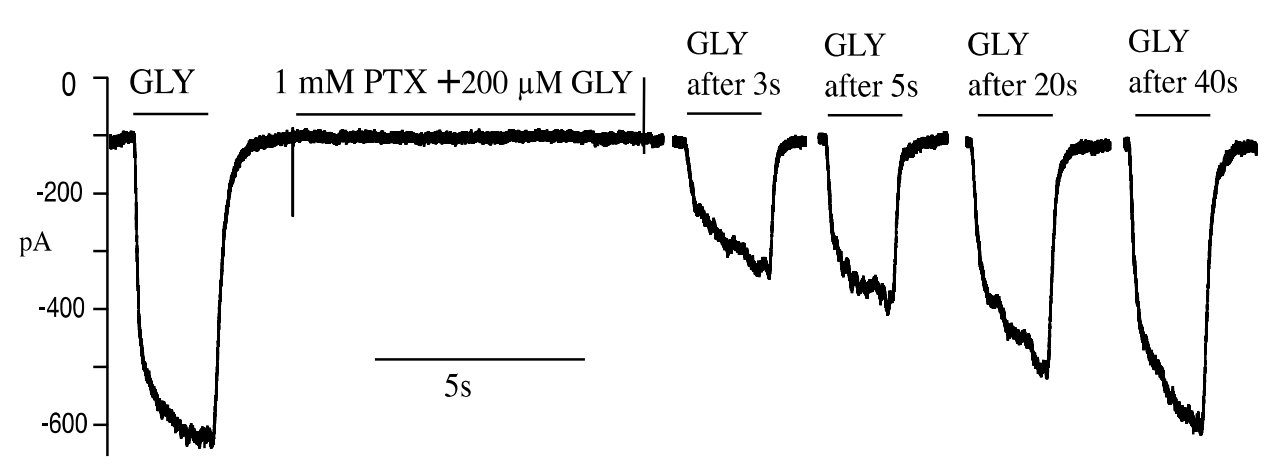

\section{PTX block of unliganded $\alpha 3$ GLYR}

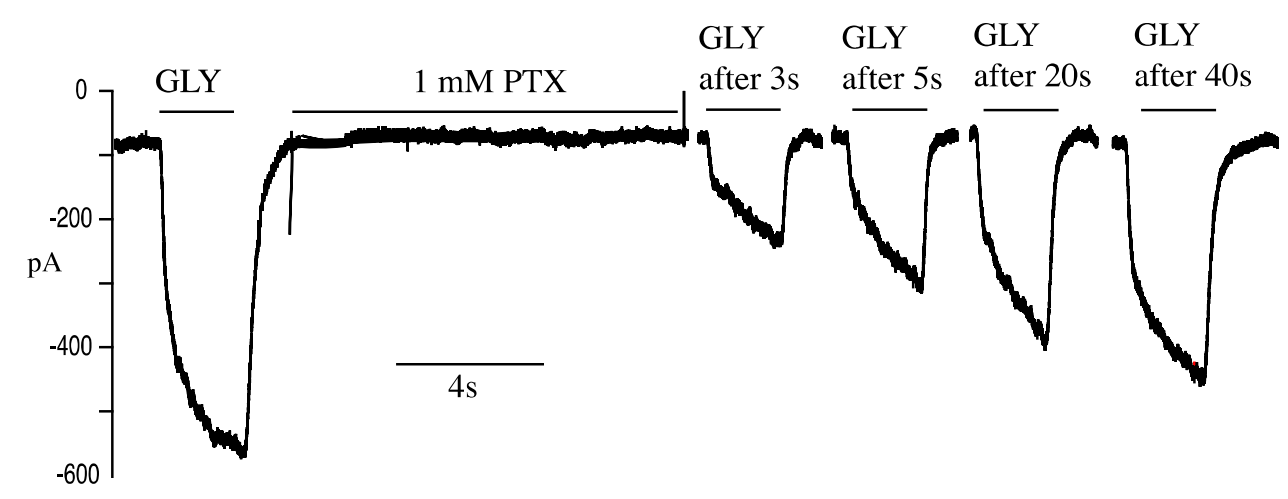

Figure 5 Picrotoxin block of liganded and unliganded homomeric alpha3 glycine receptors.

Glycine was applied before and then again after treatment with picrotoxin plus glycine (top) or picrotoxin alone (bottom). Each of the four post-picrotoxin traces represents a separate experiment in which glycine was applied sometime after picrotoxin removal, as indicated. 

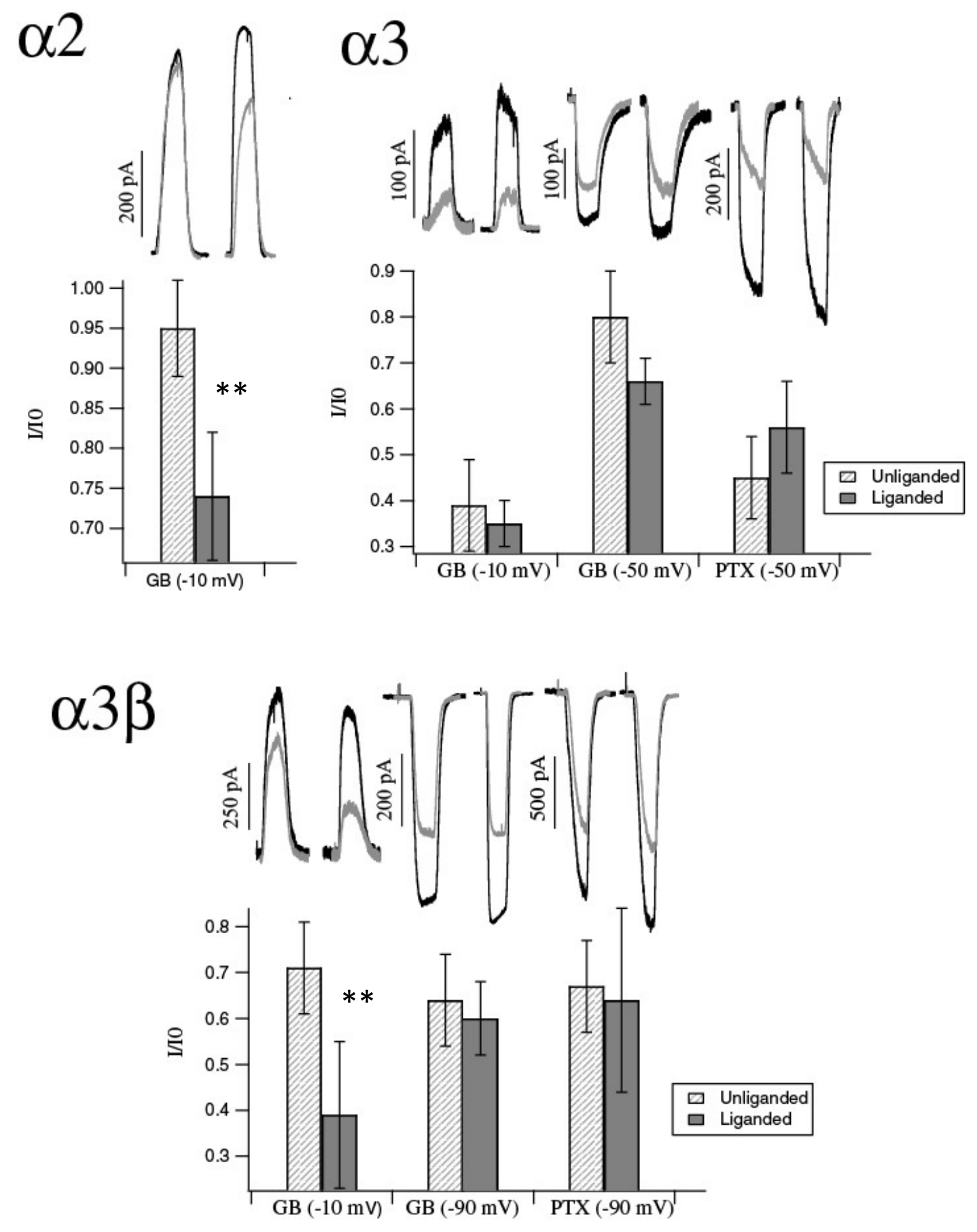

Figure 6: GB can block the unliganded glycine receptor. The figure shows blocking effects of antagonists GB and PTX in liganded and unliganded state on $\alpha 2, \alpha 3$ and $\alpha 3 \beta$ GlyRs. For all parts dashed bars represent unliganded block conditions while solid bar represents 
liganded block conditions. The raw traces above dashed bars show relative peak of the first glycine peak (black) to second glycine peak after $3 \mathrm{~s}$ wash (grey). The bars represent $\mathrm{I} / \mathrm{I}_{0}$ values where $\mathrm{I}_{0}$ is the first glycine peak and $\mathrm{I}$ is the second glycine peak. Error bars represent SD.

In $\alpha 2$ part of the figure, $\mathrm{I} / \mathrm{I}_{0}$ value for liganded state at $-10 \mathrm{mV}$ is $0.74 \pm 0.08, \mathrm{n}=12$. The unliganded block was fully recovered by $3 \mathrm{~s}\left(\mathrm{I} / \mathrm{I}_{0}=0.95 \pm 0.06, \mathrm{n}=15\right)$.

In $\alpha 3$ GlyRs, $\mathrm{I} / \mathrm{I}_{0}$ values at $-10 \mathrm{mV}$ GB unliganded was $0.39 \pm 0.1, \mathrm{n}=5$ and at $-10 \mathrm{mV}$ GB liganded was $0.35 \pm 0.05, \mathrm{n}=5$. The plotted value at $-50 \mathrm{mV}$ GB unliganded was $0.80 \pm 0.1$, $\mathrm{n}=3$ and liganded was $0.66 \pm 0.05, \mathrm{n}=4$. For PTX unliganded block, $\mathrm{I} / \mathrm{I}_{0}$ value was $0.45 \pm 0.09$, $\mathrm{n}=8$ and for PTX liganded block it was $0.56 \pm 0.1, \mathrm{n}=7$.

In $\alpha 3 \beta$ GlyRs, $\mathrm{I} / \mathrm{I}_{0}$ values at $-10 \mathrm{mV}$ GB unliganded was $0.71 \pm 0.1, \mathrm{n}=8$ and for liganded $\mathrm{GB}$ at the same voltage it was $0.39 \pm 0.16, \mathrm{n}=11$. At $-90 \mathrm{mV}$, plotted $\mathrm{I} / \mathrm{I}_{0}$ values for unliganded GB was $0.64 \pm 0.1, \mathrm{n}=8$ and liganded GB was $0.60 \pm 0.08, \mathrm{n}=7$. For PTX block, $\mathrm{I} / \mathrm{I}_{0}$ values at unliganded was $0.67 \pm 0.1, \mathrm{n}=6$ and at liganded it was $0.64 \pm 0.20, \mathrm{n}=6$. 

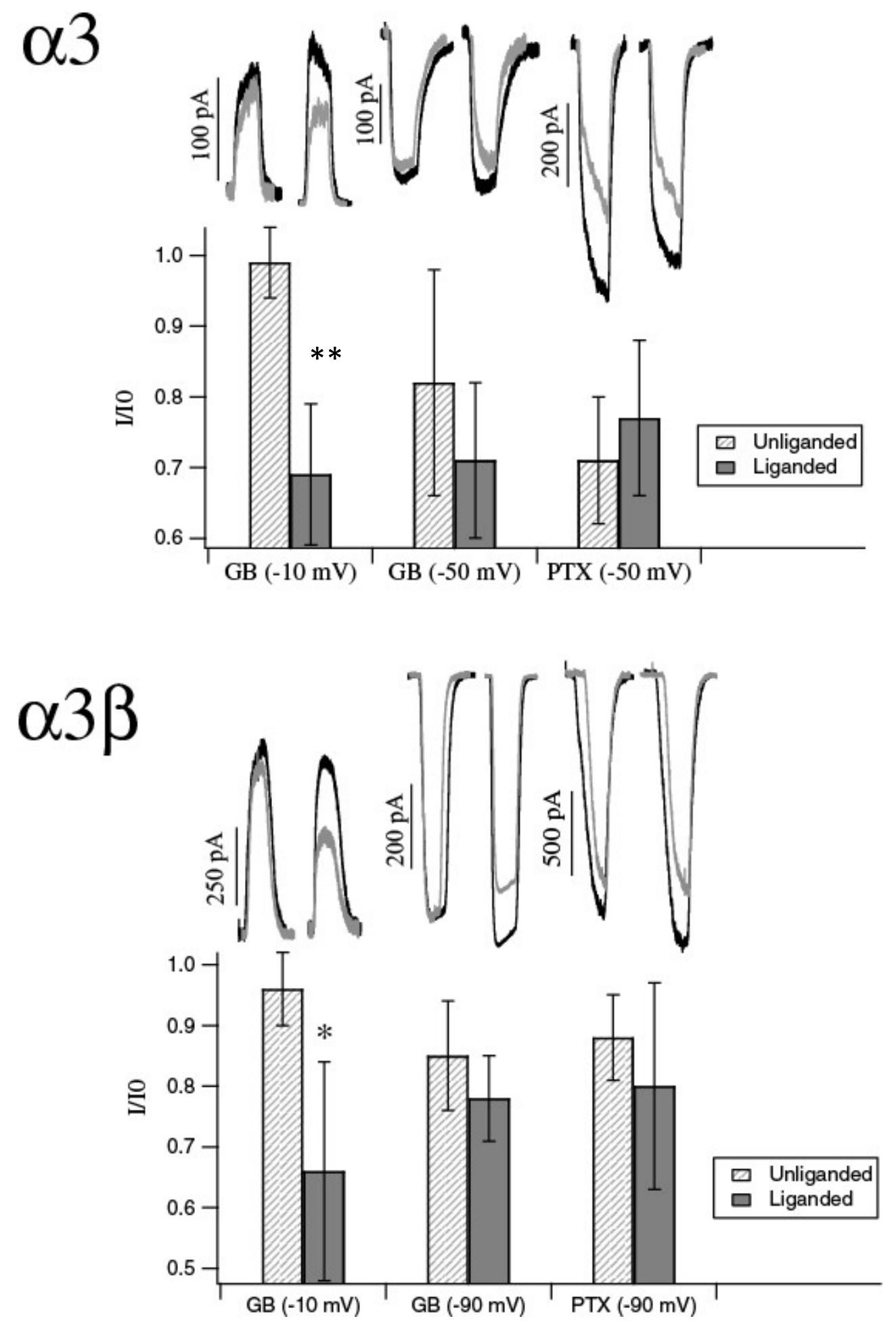

Figure 7: Recovery from GB block of glycine receptors is voltage dependent. Shows recovery from unliganded and liganded blocks of GB and PTX after 10s wash. For both 
$\alpha 3$ and $\alpha 3 \beta$ GlyRs dashed bars and the corresponding traces above that represent unliganded block while solid bars along with the raw traces above represent liganded block. In the raw traces, black shows the first glycine response and grey shows the glycine response after $10 \mathrm{~s}$ wash. The plotted values in the bar graph is $\mathrm{I} / \mathrm{I}_{0}$ values where $\mathrm{I}_{0}$ is the first glycine peak and $\mathrm{I}$ is the second glycine peak. Error bars represent SD.

$\alpha 3$ GlyRs - Plotted $\mathrm{I} / \mathrm{I}_{0}$ values for unliganded GB block at $-10 \mathrm{mV}=0.99 \pm 0.05, \mathrm{n}=5$ and liganded GB block $=0.70 \pm 0.10, \mathrm{n}=5(\mathrm{p}<0.05)$. At $-50 \mathrm{mV}$, unliganded GB block was $0.83 \pm 0.16, \mathrm{n}=3$ and liganded GB block was $0.71 \pm 0.10, \mathrm{n}=4$. With unliganded PTX block $\mathrm{I} / \mathrm{I}_{0}$ value was $0.72 \pm 0.09, \mathrm{n}=7$ and with liganded PTX $\mathrm{I} / \mathrm{I}_{0}$ was $0.77 \pm 0.11, \mathrm{n}=8$.

$\alpha 3 \beta$ GlyRs - At $-10 \mathrm{mV}, \mathrm{I} / \mathrm{I}_{0}$ values for unliganded GB block was $0.96 \pm 0.08, \mathrm{n}=6$ and liganded GB block was $0.66 \pm 0.07, \mathrm{n}=6 \mathrm{p}<0.001$. At $-90 \mathrm{mV}, \mathrm{I} / \mathrm{I}_{0}$ values for unliganded GB block was $0.85 \pm 0.09, \mathrm{n}=7$ and liganded GB block was $0.78 \pm 0.07, \mathrm{n}=6 . \mathrm{I} / \mathrm{I}_{0}$ values for unliganded PTX block was $0.88 \pm 0.07, \mathrm{n}=6$ and liganded PTX block was $0.80 \pm 0.16, \mathrm{n}=6$. 


\section{References:}

Baer K, Waldvogel Hj Fau - Faull RLM, Faull RI Fau - Rees MI, Rees MI (2009) Localization of glycine receptors in the human forebrain, brainstem, and cervical spinal cord: an immunohistochemical review.

Crook J, Hendrickson A, Robinson FR (2006) Co-localization of glycine and gaba immunoreactivity in interneurons in Macaca monkey cerebellar cortex. Neuroscience 141:1951-1959.

Das P, Dillon GH (2005) Molecular determinants of picrotoxin inhibition of 5hydroxytryptamine type 3 receptors.

Deleuze C, Runquist M Fau - Orcel H, Orcel H Fau - Rabie A, Rabie A Fau - Dayanithi G, Dayanithi G Fau - Alonso G, Alonso G Fau - Hussy N, Hussy N (2005) Structural difference between heteromeric somatic and homomeric axonal glycine receptors in the hypothalamo-neurohypophysial system.

Durisic N, Godin AG, Wever CM, Heyes CD, Lakadamyali M, Dent JA (2012) Stoichiometry of the Human Glycine Receptor Revealed by Direct Subunit Counting. The Journal of Neuroscience 32:12915-12920.

Elliott K, McQuaid S, Salto-Tellez M, Maxwell P (2015) Immunohistochemistry should undergo robust validation equivalent to that of molecular diagnostics.

Gurley D, Amin J Fau - Ross PC, Ross Pc Fau - Weiss DS, Weiss Ds Fau - White G, White $G$ (1995) Point mutations in the M2 region of the alpha, beta, or gamma subunit of the GABAA channel that abolish block by picrotoxin.

Harvey RJ, Depner UB, Wässle H, Ahmadi S, Heindl C, Reinold H, Smart TG, Harvey K, Schütz B, Abo-Salem OM, Zimmer A, Poisbeau P, Welzl H, Wolfer DP, Betz H, Zeilhofer HU, Müller U (2004) GlyR a3: An Essential Target for Spinal PGE2Mediated Inflammatory Pain Sensitization. Science 304:884-887.

Hasan ZA, Abdel Razzak RL, Alzoubi KH (2014) Comparison between the effect of propofol and midazolam on picrotoxin-induced convulsions in rat. Physiology \& Behavior 128:114-118.

Haverkamp S, Muller U Fau - Harvey K, Harvey K Fau - Harvey RJ, Harvey Rj Fau - Betz H, Betz H Fau - Wassle H, Wassle H (2003) Diversity of glycine receptors in the mouse retina: localization of the alpha3 subunit.

Hawthorne R, Lynch JW (2005) A picrotoxin-specific conformational change in the glycine receptor M2-M3 loop.

Hawthorne R, Cromer BA, Ng H-L, Parker MW, Lynch JW (2006a) Molecular determinants of ginkgolide binding in the glycine receptor pore. Journal of Neurochemistry 98:395407.

Hawthorne R, Cromer BA, Ng HL, Parker MW, Lynch JW (2006b) Molecular determinants of ginkgolide binding in the glycine receptor pore. J Neurochem 98:395-407.

Heads JA, Hawthorne RL, Lynagh T, Lynch JW (2008a) Structure-activity analysis of ginkgolide binding in the glycine receptor pore. Journal of Neurochemistry 105:14181427.

Heads JA, Hawthorne RL, Lynagh T, Lynch JW (2008b) Structure-activity analysis of ginkgolide binding in the glycine receptor pore. J Neurochem 105:1418-1427.

Heinze L, Harvey RJ, Haverkamp S, Wässle H (2007) Diversity of glycine receptors in the mouse retina: Localization of the a 4 subunit. The Journal of Comparative Neurology 500:693-707.

Huang SH, Duke RK, Chebib M, Sasaki K, Wada K, Johnston GAR (2004) Ginkgolides, diterpene trilactones of Ginkgo biloba, as antagonists at recombinant $\alpha 1 \beta 2 \gamma 2 \mathrm{~L}$ GABAA receptors. European Journal of Pharmacology 494:131-138.

Huang SH, Lewis TM, Lummis SC, Thompson AJ, Chebib M, Johnston GA, Duke RK (2012) Mixed antagonistic effects of the ginkgolides at recombinant human rho1 GABAC receptors. Neuropharmacology 63:1127-1139. 
Huang X, Shaffer PL, Ayube S, Bregman H, Chen H, Lehto SG, Luther JA, Matson DJ, McDonough SI, Michelsen K, Plant MH, Schneider S, Simard JR, Teffera Y, Yi S, Zhang M, DiMauro EF, Gingras J (2017) Crystal structures of human glycine receptor [alpha] 3 bound to a novel class of analgesic potentiators. Nat Struct Mol Biol 24:108113.

Ivic L, Sands TT, Fishkin N, Nakanishi K, Kriegstein AR, Stromgaard K (2003a) Terpene trilactones from Ginkgo biloba are antagonists of cortical glycine and GABA(A) receptors. J Biol Chem 278:49279-49285.

Ivic L, Sands Tt Fau - Fishkin N, Fishkin N Fau - Nakanishi K, Nakanishi K Fau - Kriegstein AR, Kriegstein Ar Fau - Stromgaard K, Stromgaard K (2003b) Terpene trilactones from Ginkgo biloba are antagonists of cortical glycine and GABA(A) receptors.

Kondratskaya EL, Lishko PV, Chatterjee SS, Krishtal OA (2002) BN52021, a platelet activating factor antagonist, is a selective blocker of glycine-gated chloride channel. Neurochemistry International 40:647-653.

Kondratskaya EL, Fisyunov AI, Chatterjee SS, Krishtal OA (2004) Ginkgolide B preferentially blocks chloride channels formed by heteromeric glycine receptors in hippocampal pyramidal neurons of rat. Brain Research Bulletin 63:309-314.

Kondratskaya EL, Betz H, Krishtal OA, Laube B (2005) The $\beta$ subunit increases the ginkgolide $B$ sensitivity of inhibitory glycine receptors. Neuropharmacology 49:945951.

Lynch JW (2009) Native glycine receptor subtypes and their physiological roles. Neuropharmacology 56:303-309.

Lynch JW, Rajendra S Fau - Barry PH, Barry Ph Fau - Schofield PR, Schofield PR (1995) Mutations affecting the glycine receptor agonist transduction mechanism convert the competitive antagonist, picrotoxin, into an allosteric potentiator.

Maclennan KM, Darlington CL, Smith PF (2002) The CNS effects of Ginkgo biloba extracts and ginkgolide B. Progress in Neurobiology 67:235-257.

Pribilla I, Takagi T, Langosch D, Bormann J, Betz H (1992) The atypical M2 segment of the beta subunit confers picrotoxinin resistance to inhibitory glycine receptor channels. The EMBO Journal 11:4305-4311.

Shan Q, Haddrill JI Fau - Lynch JW, Lynch JW (2001a) A single beta subunit M2 domain residue controls the picrotoxin sensitivity of alphabeta heteromeric glycine receptor chloride channels.

Shan Q, Haddrill JL, Lynch JW (2001b) A single beta subunit M2 domain residue controls the picrotoxin sensitivity of alphabeta heteromeric glycine receptor chloride channels. J Neurochem 76:1109-1120.

Turecek R, Trussell LO (2002) Reciprocal developmental regulation of presynaptic ionotropic receptors.

Wang D-S, Mangin J-M, Moonen G, Rigo J-M, Legendre P (2006) Mechanisms for Picrotoxin Block of $\alpha 2$ Homomeric Glycine Receptors. Journal of Biological Chemistry 281:3841-3855.

Xu T-L, Gong N (2010) Glycine and glycine receptor signaling in hippocampal neurons: Diversity, function and regulation. Progress in Neurobiology 91:349-361.

Zhang D, Pan Zh Fau - Zhang X, Zhang X Fau - Brideau AD, Brideau Ad Fau - Lipton SA, Lipton SA (1995) Cloning of a gamma-aminobutyric acid type $C$ receptor subunit in rat retina with a methionine residue critical for picrotoxinin channel block. 